\title{
UPAYA MENINGKATKAN HASIL BELAJAR MATEMATIKA MELALUI GUIDED DISCOVERY LEARNING DENGAN PENDEKATAN SAINTIFIK MATERI OPERASI HIMPUNAN
}

\author{
Nera Prabawati' ${ }^{1)}$, Muslimin'), ${ }^{2}$ eru ${ }^{3)}$ \\ ${ }^{1)}$ Sekolah Menengah Pertama Muhammadiyah 1 Palembang, ${ }^{2) 3}$ Fakultas Keguruan dan Ilmu \\ Pendidikan Universitas Muhammadiyah Palembang \\ ${ }^{1)}$ email: prabawati1988@gmail.com \\ ${ }^{2)}$ email: muslimintr@gmail.com \\ ${ }^{3)}$ email: heroe.ump@gmail.com
}

\begin{abstract}
This study aims to describe the efforts to improve learning outcomes in the set operation material with guided discovery learning and describe student responses to set operation learning through guided discovery learning. This research is a class action research. Research conducted at Muhammadiyah 1 Junior High School Palembang. The results showed that the application of set operation learning with the guided discovery learning model proved effective in improving the learning outcomes of class VII student operations collection at SMP Muhammadiyah 1 Palembang, and students' responses to the learning were positive and generally students expressed pleasure in participating in learning and could understand the material of operations the set well. For this reason, mathematics learning through the guided discovery learning model can be used as an alternative learning in school.
\end{abstract}

Keywords: improve, learning outcomes, guided discovery learning, scientific

\begin{abstract}
Abstrak
Penelitian ini bertujuan untuk mendeskripsikan upaya meningkatkan hasil belajar pada materi operasi himpunan dengan guided discovery learning dan mendeskripsikan respon siswa terhadap pembelajaran operasi himpunan melalui guided discovery learning. Penelitian ini merupakan penelitian tindakan kelas. Penelitian yang dilaksanakan di SMP Muhammadiyah 1 Palembang. Hasil penelitian menunjukkan bahwa penerapan pembelajaran operasi himpunan dengan model guided discovery learning tersebut, ternyata efektif meningkatkan hasil belajar operasi himpunan siswa kelas VII SMP Muhammadiyah 1 Palembang, dan respon siswa terhadap pembelajaran tersebut adalah positif dan umumnya siswa menyatakan senang mengikuti pembelajaran dan bisa memahami materi operasi himpunan dengan baik. Untuk itu, agar pembelajaran matematika melalui model guided discovery learning dapat dijadikan salah satu alternatif pembelajaran di sekolah
\end{abstract}

Kata kunci : meningkatkan, hasil belajar, guided discovery learning, saintifik 


\section{PENDAHULUAN}

Perkembangan ilmu pengetahuan dan teknologi saat ini memasuki era revolusi industri 4.0. hal ini menuntut kita untuk memiliki keterampilan manusia abad 21. Berdasarkan "21st Century Partnership Learning Framework", terdapat beberapa kompetensi dan/atau keahlian yang harus dimiliki oleh SDM abad XXI, yaitu: 1) kemampuan berpikir kritis dan pemecahan masalah; 2) kemampuan berkomunikasi dan bekerjasama; 3) kemampuan mencipta dan membaharui; 4) literasi teknologi informasi dan komunikasi; 5) kemampuan belajar kontekstual; 6) kemampuan informasi dan literasi media (Indrajit, 2011). Untuk memberoleh keterampilan tersebut tidak terlepas dari tanggung jawab guru/pendidik terutama mempersiapkan siswa menjadi subjek yang kreatif, mandiri dan profesional pada bidangnya masing-masing. Salah satu kegiatan untuk menghasilkan sumber daya manusia yang bermutu tinggi adalah melalui pendidikan matematika, karena matematika sebagai ilmu dasar yang terpakai di segala bidang ilmu pengetahuan. Saat ini matematika telah berkembang sangat pesat baik materi maupun kegunaannya. Mengingat pelajaran matematika yang sangat penting itulah maka sudah seharusnya guru dan semua pihak yang terlibat dalam pendidikan matematika berupaya agar pendidikan matematika dapat berhasil sesuai dengan yang diharapkan.

Dalam upaya mencapai tujuan pendidikan nasional seorang guru tidak hanya sebagai pengajar dan pembimbing saja, tetapi juga sebagai pendidik yang menjadi contoh, panutan, model bagi siswa dan lingkungannya, sebagai pelajar yang dituntut selalu menambah pengetahuan dan keterampilan agar tidak ketinggalan zaman. Selain itu guru juga sebagai komunikator, administrator, dan aktor yang jujur (Sadirman, 2014). Misi utama guru matematika sebagai pengajar adalah tercapainya tujuan-tujuan instruksional matematika, sedangkan misi guru matematika sebagai pendidik adalah mengupayakan terwujudnya perkembangan siswa dalam arti yang lebih luas. Sejalan dengan pikiran di atas, tugas guru matematika tidak hanya sekedar diperolehnya berbagai pengetahuan dan keterampilan matematika oleh siswa. Namun, tugas guru juga mendorong dan memberi memotivasi berkembangnya pemahaman dan penghayatan terhadap prinsip, nilai dan proses bermatematika, menumbuhkan daya nalar, berpikir logis, sistematik, kritik, cerdas, rasa keindahan, terbuka dan rasa ingin tahu pada siswa.

Dengan kata lain, tugas guru matematika adalah membimbing siswa memiliki pengetahuan dan nilai matematika, melaksanakan proses bermatematika, serta menumbuhkan rasa senang dan cinta belajar matematika di kalangan siswa, sebab selama 
ini dalam berbagai hasil penelitian menunjukkan bahwa pelajaran matematika adalah pelajaran yang sulit serta tidak disukai oleh siswa (Jihad, 2008)

Walaupun siswa sudah berusaha untuk mengikuti bimbingan belajar, mengerjakan pekerjaan rumah sebagai latihan menyelesaikan soal-soal, tetapi nilai yang diperoleh siswa tetap saja tidak memuaskan, dalam artian hasil belajar siswa masih rendah (Muslimin, 2006). Pada saat siswa memahami pelajaran matematika, dapat mengakibatkan kurangnya minat siswa untuk mengikuti dan menekuni pelajaran matematika tersebut. Minat besar mempengaruhi siswa untuk tekun belajar matematika karena bila bahan pelajaran yang dipelajari tidak sesuai dengan minat, maka siswa tidak akan belajar dengan sebaik-baiknya dan mangalami kesulitan dalam mengaplikasikan matematika ke dalam situasi nyata. Hal lain yang menjadi penyebab sulitnya matematika bagi siswa karena siswa tidak ikut melakukan percobaan dengan membuktikan sendiri sesuatu yang dipelajari dalam kehidupan sehari-hari sehingga proses pembelajaran kurang bermakna.

Untuk itulah upaya meningkatkan kualitas pendidikan terus menerus dilakukan. Salah satu usaha yang dilakukan pemerintah adalah memberlakukan kurikulum 2013. Ciri kurikulum 2013, yaitu menggunakan pendekatan saintifik yang menurut (Majid \& Rohman, 2013) memiliki karakteristik sebagai berikut. 1) Berpusat pada peserta didik, 2) Melibatkan keterampilan proses sains dalam mengonstruksi konsep, hukum, atau prinsip, 3) Melibatkan proses-proses kognitif yang potensial dalam merangsang perkembangan intelek, khususnya keterampilan berpikir tingkat tinggi peserta didik,dan 4) Dapat mengembangkan karakter peserta didik.

Dengan pendekatan saintifik dan menggunakan model pembelajaran yang tepat akan membuat siswa aktif dan senang membangun sendiri pengetahuan matematikanya. Namun hasil pengamatan peneliti di kelas VII SMP Muhammadiyah 1 Palembang masih terlihat guru yang lebih dominan dalam proses belajar mengajar dibandingkan siswa. Pada saat memulai pembelajaran matematika, guru langsung memberikan penjelasan konsep rumus kepada siswa dan pembelajaran yang diterapkan di kelas VII SMP Muhammadiyah 1 Palembang, masih mengacu kepada cara belajar menurut kurikulum KTSP dan ternyata hasil ulangan harian diperoleh nilai rata-rata siswa dibawah KKM yang telah ditetapkan dalam persen yaitu $70 \%$. Kenyataan tersebut tentunya akan berdampak pada rendahnya hasil belajar matematika siswa di kelas VII SMP Muhammadiyah1 Palembang pada materi himpunan khususnya operasi himpunan. Oleh 
karena itu, sudah saatnya dialihkan pada pembelajaran yang mengacu pada paham konstruktivisme. Salah satunya adalah pembelajaran melalui model guided discovery learning.

Model guided discovery learning merupakan model pembelajaran yang berusaha membuat pembelajaran matematika menjadi bermakna dibenak siswa adalah dengan mengacu pada model pembelajaran yang dapat membimbing siswa menemukan sendiri konsep materi yang akan dipelajari. Model pembelajaran yang dimaksud adalah model pembelajaran penemuan terbimbing (guided discovery learning) yang merupakan modifikasi dari model pembelajaran penemuan (discovery learning) yang dipopulerkan oleh (Bruner, 1966). Bruner dalam (Tung, 2015) berpendapat bahwa proses belajar akan berjalan dengan baik dan kreatif jika guru memberi kesempatan kepada siswa untuk menemukan aturannya sendiri melalui konsep, teori, definisi, dan sebagainya. Pada penemuan terbimbing bentuk bimbingan yang diberikan guru dapat berupa petunjuk, arahan, pertanyaan atau dialog, sehingga diharapkan siswa dapat menyimpulkan (menggeneralisasikan) sesuai dengan rancangan guru (Setiani \& Prian, 2015).

\section{METODE PENELITIAN}

Penelitian ini mendeskripsikan upaya meningkatkan hasil belajar matematika melalui guided discovery learning dengan pendekatan saintifik (scientific approach) pada materi operasi himpunan di SMP Muhammadiyah 1 Palembang. Penelitian ini merupakan penelitian tindakan kelas. Penelitian tindakan kelas merupakan suatu pengamatan terhadap kegiatan belajar berupa sebuah tindakan, yang sengaja dimunculkan dan terjadi dalam sebuah kelas secara bersama. Tindakan tersebut diberikan oleh guru atau dengan arahan dari guru yang dilakukan oleh siswa (Arikunto, 2008).

Penelitian ini bersifat deskritif kualitatif, yaitu pengumpulan data yang berupa uraian-uaraian atau kalimat dan bukan angka-angka. Pendekatan penelitian ini adalah pendekatan kualitatif karena memiliki ciri-ciri yang sesuai dengan penelitian kualitatif yang dikemukakan oleh Bogdan dan Biklen (dalam Muslimin, 2006) dengan ciri-ciri tersebut adalah sebagai berikut. (1) mempunyai latar alami sebagai sumber data langsung, data yang diperoleh dan diteliti akan dipaparkan apa adanya, (2) peneliti sebagai instrumen utama, (3) bersifat deskritif, karena data yang dikumpulkan berbentuk uraianuraian, bukan bentuk angka dan lebih mementingkan proses pembelajaran dari pada hasil, 
(4) analisis pada data cendrung bersifat deduktif, (5) makna merupakan masalah esensial, karena terpusat pada kegiatan siswa dalam memahami materi pembelajaran.

Sesuai dengan pendekatan dan jenis penelitian yang telah dikemukakan sebelumnya maka kehadiran penelitian dilapangan mutlak diperlukan. Peneliti sebagai instrumen utama dan pengamat yang mengamati aktivitas yang terjadi selama pengamatan berlangsung. Sebagai pemberi tindakan penelitian, peneliti bertindak sebagai guru yang memuat rancangan pembelajaran dan sekaligus menyampaikan bahan ajar selama kegiatan pembelajaran berlangsung. Disamping itu juga peneliti sebagai pengumpul data dan penganalisis data serta sebagai pelapor hasil penelitian. Dalam kegiatan pengamatan dan pengumpulan data, peneliti sebagai guru di SMP Muhammadiyah 1 Palembang dibantu oleh dua orang pengamat, yaitu guru bidang studi matematika kelas VII. 3 SMP Muhammadiyah 1 Palembang dan seorang Dosen dari Jurusan Pendidikan Matematika Universitas Muhammadiyah Palembang yang melaksanakan program hibah PDS.

Sumber data dalam penelitian ini adalah (1) hasil jawaban dari tes akhir siswa yang diberikan oleh peneliti tentang materi operasi himpunan, (2) hasil observasi diperoleh dari pengamatan pelaksanaan tindakan pembelajaran, (3) hasil angket siswa terhadap proses pembelajaran materi operasi himpunan dengan menggunakan pembelajaran model guided discovery learning setelah penelitian dilakukan. Sumber data tentang hasil jawaban siswa dalam menyelesaikan soal-soal tes tentang materi operasi himpunan dan hasil angket respon siswa terhadap proses pembelajaran materi operasi himpunan dengan menggunakan pembelajaran model guided discovery learning dalam penelitian ini diperoleh dari siswa kelas VII.1 SMP Muhammadiyah 1 Palembang tahun pelajaran 2018/2019, sedangkan hasil observasi diperoleh dari pengamatan guru bidang studi matematika kelas VII.3 SMP Muhammadiyah 1 Palembang dan seorang dosen dari Program Studi Pendidikan Matematika Universitas Muhammadiyah Palembang. Data yang dijaring dalam penelitian ini adalah (1) skor hasil tes siswa dalam menyelesaikan soal-soal tes yang diberikan pada setiap tindakan, (2) hasil observasi diperoleh dari hasil pengamatan guru bidang studi matematika kelas $\mathrm{VII}_{3}$ dan dosen pada saat berlangsungnya kegiatan pembelajaran dengan menggunakan lembar observasi, dan (3) hasil angket siswa diperoleh dari respon siswa terhadap proses pembelajaran operasi himpunan dengan menggunakan pembelajaran model guided discovery learning.

Data hasil penelitian yang terkumpul, di analisis dengan model air (flow model) yang meliputi tahap-tahap sebagai berikut. (1) mereduksi data, (2) penyajian data, dan (3) 
penarikan kesimpulan. Analisis statistik deskriptif dilakukan terhadap data yang bersifat kuantitatif. Data hasil tes dianalisis dengan acuan terhadap pencapaian nilai rata-rata untuk mengetahui tingkat penguasaan dalam bentuk persentase. Subyek dianggap tuntas belajar apabila mencapai nilai KKM 75\% atau lebih. Bila nilai rata-rata KKM yang diperoleh subyek kurang dari 75\% dianggap belum tuntas belajarnya, sehingga subyek tersebut perlu mendapatkan tindakan berikutnya. Data hasil tes akhir dianalisis untuk mengetahui ketuntasan tujuan Pembelajaran dan ketuntasan belajar seluruh siswa dalam kelas.

Untuk mengetahui aktivitas guru dan siswa melalui aktivitas subyek selama pembelajaran, data yang terdapat dalam lembar observasi akan dihitung rata-rata frekuensi aktivitas yang tercatat oleh dua orang pengamat dalam setiap siklus. Jadi indikator keberhasilan setiap siklus ditunjukan oleh 1) nilai rata-rata dalam bentuk persen hasil observasi proses aktivitas guru dan siswa $\geq 85 \%$ dan 2) Nilai hasil tes berupa ratarata mencapai $\mathrm{KKM} \geq 75 \%$. Selanjutnya untuk menjawab bagaimana respon siswa terhadap pembelajaran, yaitu juga dengan menggunakan persentase. Kategori respon siswa digolongkan kedalam 4 kategori, yaitu sangat positif, positif, negatif, sangat negatif.

Pengecekan keabsahan data dalam penelitian ini menggunakan teknik triangulasi, digunakan untuk memeriksa keabsahan data yang memanfaatkan sesuatu yang lain di luar data itu untuk keperluan pengecekan atau pembanding terhadap data tersebut (Meleong, 2012). Triangulasi yang dilakukan meliputi triangulasi metode, triangulasi sumber dan triangulasi teori.

\section{HASIL DAN PEMBAHASAN}

Data hasil penelitian melalui dua tindakan dengan masing-masing siklus, Tindakan Siklus 1 terdiri dari 1) Aktivitas dalam proses pembelajaran hasil observasi, selama pelaksanaan tindakan I siklus 1 menunjukkan bahwa aktivitas diskusi masih berjalan lamban dan kurang aktif. Di samping itu masih ada siswa yang cenderung bekerja sendiri, ini menandakan bahwa mereka belum bisa menyesuaikan pembelajaran matematika model guided discovery learning dengan pendekatan saintifik pada materi operasi himpunan. 2) Hasil belajar melalui tes, data perolehan hasil tes tindakan I siklus 1 menunjukkan bahwa proses pembelajaran yang berupa aktivitas guru dan siswa diperoleh presentasi nilai rata-rata presentasi adalah $83 \%$, berarti belum memenuhi kriteria yang 
ditentukan $85 \%$ dan nilai hasil belajar, persentase nilai rata-rata subjek penelitian adalah $67,3 \%$ berarti kriteria tingkat keberhasilan di bawah 75\%, ini juga menunjukkan belum masuk kriteria ketuntasan yang telah ditentukan. Dengan mempertimbangkan ketuntasan belajar dan efektifitas kegiatan diskusi masih kurang, diputuskan untuk dilanjutkan dengan pemberian tindakan I siklus 2 .

Tindakan Siklus 2 terdiri dari 1) Aktivitas dalam proses pembelajaran hasil observasi. Selama pelaksanaan tindakan I siklus 2, kegiatan diskusi siswa sudah mulai hidup dari sebelumnya dan mulai terlihat adanya keterampilan belajar model guided discovery learning dalam kelompok. Di samping itu siswa mulai dapat membangun kerja sama dalam kelompok tanpa membedakan jenis kelamin, melainkan sudah mulai terlihat kecenderungan subjek berkemampuan akademik tinggi menjadi tempat bertanya bagi anggota kelompoknya. Secara umum aktivitas diskusi sudah mencapai kategori sedang. Ini berarti aktivitas Guru utamanya aktivitas siswa mengalami peningkatan. Hal ini ditunjukkan hasil rata-rata prosentasinya adalah 85,2\%. 2) Hasil belajar melalui tes, data hasil tes tindakan I siklus 2 menunjukkan bahwa rata-rata tingkat penguasaan materi adalah 69,5\%. Hal ini berarti bahwa terjadi peningkatan penguasaan materi bila dibandingkan dengan siklus 1 yang hanya mencapai 67,3\%. Angka prosentase tersebut belum memenuhi kriteria yang ditetapkan, yaitu $\geq 75 \%$. Walaupun kriteria proses pembelajaran sudah mencapai kriteria yang ditentukan, namun kriteria hasil tes belum memenuhi. Untuk itu, masih perlu dilanjutkan ke tindakan siklus 3.

Tindakan Siklus 3 terdiri dari 1) Aktivitas dalam proses pembelajaran hasil observasi, selama pelaksanaan tindakan I siklus 3, intesitas kerja sama dan peran siswa semakin meningkat, kecendrungan berdiskusi berdasarkan kesamaan jenis kelamin tidak terjadi lagi, tanggung jawab subyek berkemampuan akademik tinggi terhadap temantemannya atas penguasaan materi yang dipelajari sudah lebih menonjol, aktivitas diskusi dan keterampilan dalam pembelajaran melalui model guided discovery learning semakin mendekati maksimal. Hal ini ditunjukkan hasil rata-rata prosentasinya adalah $89,3 \%$, dengan demikian dari siklus $1=83 \%$, siklus $2=85,2 \%$, dan siklus $3=90,3 \%$, mengalami peningkatan. 2) Hasil belajar melalui tes, data hasil tes tindakan siklus 3 juga mengalami peningkatan dari siklus sebelumnya, yaitu dari 69,5\% menjadi 84,5\%. Data telah menunjukkan ketuntasan belajar, yaitu telah $>75 \%$. Hal ini berarti bahwa pada siklus 3 , terjadi peningkatan penguasaan materi bila dibandingkan dengan siklus 1 dan 2 . 
Berdasarkan hasil temuan dan hasil refleksi di atas, peneliti bersama guru matematika dan pengamat memutuskan bahwa penelitian sudah berhasil dan dapat membuat laporan hasil penelitian.

Respon Siswa, pada umumnya siswa menyatakan senang terhadap pembelajaran model guided discovery learning pada materi operasi himpunan untuk meningkatkan hasil belajar matematika siswa. Hal Ini ditunjukan dengan keaktifan siswa dalam mengikuti pembelajaran. Terkadang siswa juga menunjukan perasaan senang dengan memberikan aplaus pada teman yang selesai mempersentasikan hasil kelompoknya di papan tulis. Rasa senang siswa ini dapat disebabkan beberapa faktor berikut: (1) siswa senang karena pembelajaran model guided discovery learning ini adalah pertama kali mereka alami sehingga tidak membosankan dan tentunya akan lebih menarik bagi siswa. (2) siswa senang karena pembelajaran model guided discovery learning memberi kesempatan kepada siswa untuk mengungkapkan berbagai gagasan tentang topik yang dibahas dalam pembelajaran yaitu mengenai persegi panjang sehingga melatih siswa bernalar dan berargumentasi sesamanya secaralogis. (3) siswa senang karena siswa sendiri yang mengkonstruksi pengetahuannya sehingga meteri dapat dimengerti secara bermakna. (4) siswa senang karena guru bertindak sebagai fasilitator pengorganisasian materi dan mengkondisikan agar siswa dapat menemukan pengetahuan dengan berinteraksi dengan sesama siswa.

\section{SIMPULAN}

Berdasarkan hasil analisis data dan pembahasan sebagaimana telah diuraikan sebelumnya, dapat disimpulkan bahwa pembelajaran matematika model guided discovery learning meningkatkan aktivitas belajar siswa dalam meraih hasil belajarnya. Respon siswa terhadap pembelajaran operasi himpunan melalui pembelajaran model guided discovery learning di kelas VII 1 SMP Muhammadiyah 1 Palembang adalah positif, karena umumnya siswa menyatakan senang mengikuti pembelajaran dan mudah memahami materi operasi himpunan.

Bila akan melakukan pembelajaran suatu materi dengan menggunakan pembelajaran model guided discovery learning, sebaiknya mengacu pada langkahlangkah pembelajaran seperti dalam penelitian ini, karena ternyata pembelajaran dalam penelitian ini dapat meningkatkan hasil belajar matematika siswa pokok himpunan pada materi operasi himpunan siswa kelas VII SMP Muhammadiyah 1 Palembang dengan baik 
dan efektif. Selanjutnya pembelajaran model guided discovery learning dapat dijadikan salah satu alternative pembelajaran bagi guru bidang studi matematika kelas VII SMP Muhammadiyah 1 Palembang. 


\section{DAFTAR PUSTAKA}

Arikunto, S. (2008). Penelitian Tindakan Kelas. Jakarta: Bumi Aksara.

Bruner, J. S. (1966). Toward a Theory of Intruction. Cambridge: Harvad University.

Indrajit, R. E. (2011). Teknologi Informasi dan Perguruan Tinggi: Menjawab Tantangan Pendidikan Abad ke-21. Jakarta: Aptikom.

Jihad, A. (2008). Pengembangan Kurikulum Matematika. Yogyakarta: Multi Pressindo.

Majid, \& Rohman. (2013). Pendekatan Ilmiah dalam Implementasi Kurikulum. Bandung: Remaja Rosdakarya.

Moleong. (2012). Metodologi Penelitian Kualitatif. Edisi revisi. Malang: Remaja Rosdakarya.

Muslimin. (2006). Belajar Kooperatif Model Jigsaw untuk Memahami Sistem Kongruensi Dua Peubah. Wawasan Kependidikan, 48-49.

Sardiman, A. M. (2012). Intraksi dan Motivasi Belajar Mengajar. Jakarta: Raya Grapindo Persada.

Setiani, \& Priana, A. J. (2015). Manajemen Peserta Didik dan Model Pembelajaran: Cerdas, Kreatif, dan Inovatif. Bandung: C.V. Alfabeta.

Tung, K. Y. (2015). Pembelajaran dan perkembangan belajar. Kembangan- Jakarta Barat: PT Indeks Permata Puri Media. 